\title{
Synthesis of Porous Material from Coal Gasification Fine Slag Residual Carbon and Its Application in Removal of Methylene Blue
}

\author{
Yixin Zhang ${ }^{1,2}$, Rumeng Wang ${ }^{3}$, Guofeng Qiu ${ }^{3}$, Wenke Jia ${ }^{3}$, Yang Guo ${ }^{3}{ }^{(}$, Fanhui Guo ${ }^{3, *}$ and Jianjun Wu ${ }^{3, *}$ \\ 1 National Engineering Research Center of Coal Preparation and Purification, China University of Mining \\ and Technology, No. 1 Daxue Road, Xuzhou 221116, China; yixinzhang@cumt.edu.cn \\ 2 Shandong Xuanyuan Scientific Engineering and Industrial Technology Research Institute Co., Ltd., \\ Longgu, Juye, Heze 274918, China \\ 3 School of Chemical Engineering and Technology, China University of Mining and Technology, \\ No. 1 Daxue Road, Xuzhou 221116, China; rumengwang@cumt.edu.cn (R.W.); \\ ts20040045a31@cumt.edu.cn (G.Q.); jwk0812@163.com (W.J.); cumt-guoyang@cumt.edu.cn (Y.G.) \\ * Correspondence: fanhuiguo@cumt.edu.cn (F.G.); wujj@cumt.edu.cn (J.W.); Tel.: +86-152-5203-1822 (F.G.); \\ +86-139-5135-0506 (J.W.)
}

check for updates

Citation: Zhang, Y.; Wang, R.; Qiu, G.; Jia, W.; Guo, Y.; Guo, F.; Wu, J. Synthesis of Porous Material from Coal Gasification Fine Slag Residual Carbon and Its Application in Removal of Methylene Blue. Molecules 2021, 26, 6116. https:// doi.org/10.3390/molecules26206116

Academic Editors: Binglin Guo, Quanzhi Tian and Chuncai Zhou

Received: 19 September 2021

Accepted: 7 October 2021

Published: 10 October 2021

Publisher's Note: MDPI stays neutral with regard to jurisdictional claims in published maps and institutional affiliations.

Copyright: (c) 2021 by the authors. Licensee MDPI, Basel, Switzerland. This article is an open access article distributed under the terms and conditions of the Creative Commons Attribution (CC BY) license (https:/ / creativecommons.org/licenses/by/ $4.0 /)$.
Abstract: A large amount of coal gasification slag is produced every year in China. However, most of the current disposal is into landfills, which causes serious harm to the environment. In this research, coal gasification fine slag residual carbon porous material (GFSA) was prepared using gasification fine slag foam flotation obtained carbon residue (GFSF) as raw material and an adsorbent to carry out an adsorption test on waste liquid containing methylene blue (MB). The effects of activation parameters (GFSF/ $\mathrm{KOH}$ ratio mass ratio, activation temperature, and activation time) on the cation exchange capacity (CEC) of GFSA were investigated. The total specific surface area and pore volume of GSFA with the highest CEC were $574.02 \mathrm{~m}^{2} / \mathrm{g}$ and $0.467 \mathrm{~cm}^{3} / \mathrm{g}$, respectively. The degree of pore formation had an important effect on CEC. The maximum adsorption capacity of GFSA on MB was $19.18 \mathrm{mg} / \mathrm{g}$ in the MB adsorption test. The effects of $\mathrm{pH}$, adsorption time, amount of adsorbent, and initial MB concentration on adsorption efficiency were studied. Langmuir isotherm and quasi second-order kinetic model have a good fitting effect on the adsorption isotherm and kinetic model of MB.

Keywords: coal gasification slag; residual carbon activation; methylene blue adsorption; kinetics; isotherms

\section{Introduction}

Coal is one of the most economical and safe primary energies that can be used cleanly and efficiently. It is widely used in many industries such as electric power, iron and steel, metallurgy, chemical, and building materials. Coal accounts for more than $50 \%$ of China's primary energy production and consumption structure, and China is the largest consumer of coal [1,2]. With the change in the world's climate and environment, the clean and efficient use of coal is particularly important.

Coal gasification technology is an important part of the clean and efficient utilization of coal resources. The residue produced in the process of coal gasification includes fine slag (GFS) and coarse slag (GCS). GCS is produced in the slag discharge mouth of the gasifier; GFS is mainly produced in the dust removal device of syngas [3,4]. Until now, the main treatment methods for gasification slag are storage and disposal in a landfill, which cause serious environmental pollution and waste of land resources. Therefore, it is urgent to develop economic, environmental, and efficient treatment methods for gasification slag [5-8]. 
Researchers have studied the physical and chemical properties of GFS [4,9-12]. GFS is composed of mineral-rich particles and residual carbon [13]. The content of residual carbon in GFS can reach more than 30\%. The mineral-rich particles in GFS mainly consist of crystalline minerals (silicates, aluminosilicates, and $\mathrm{Ca}-\mathrm{Fe}$ oxides) and vitreous components (Ca-Fe-aluminosilicate glass) [9]. At present, most GFS is used by blending. The utilization of building materials and the mixing of circulating fluidized bed boilers are the main ways coal gasification slag is used [14]. The residual carbon in the GFS has been carbonized to a certain extent in the high-temperature gasifier. Wagner, et al. [15] discovered that the residual carbon in gasification slag has a high specific surface area and micropore area, which could potentially be used as activated carbon or precursors for premium carbon products. The use of residual carbon in coal gasification slag to prepare porous materials not only provides a new possibility for the recycling of GFS but also eliminates a certain environmental pressure. There has been some research on the preparation of activated carbon from gasification slag [16-19]. Miao, et al. [17] used GFS as a raw material to prepare activated carbon through acid treatment and $\mathrm{KOH}$ activation, which was used for $\mathrm{CO}_{2}$ capture. $\mathrm{Xu}$ and Chai [18] prepared coal gasification slag-based activated carbon loaded with $\mathrm{Fe}^{3+}$ by an impregnation method, and achieved good results in the degradation of methyl orange in dye wastewater. However, although the materials obtained by these processes can obtain better properties, they cannot meet the requirements of large-scale industrialization due to their complicated operation and high cost.

With the rapid development of the printing and dyeing industry, a large amount of dye wastewater has seriously endangered human health and the environment [20]. Methylene blue (MB) is a cationic dye used for dyeing cotton, hemp, silk, paper, and so on. MB has some harmful effects on the body, including burning of the eyes, which can cause permanent damage, increased heart rate, nausea, vomiting, and shock [21-23]. At present, the treatment technology for dye wastewater includes physical (adsorption and membrane filtration), chemical (coagulation/flocculation and chemical oxidation), and biological methods [24,25]. Among them, adsorption is considered to be one of the simplest, most effective, and least costly technologies [26]. The adsorption process is simple, the equipment requirements are low, and solid waste can be used as raw material synthesis adsorbent, such as fly ash to synthesize zeolite, and activated carbon from coal gasification slag $[17,27]$. The cation exchange capacity (CEC) can be determined for the evaluation of the performance of the adsorbent. CEC depends on the number of adsorption sites of the material, which can be used as one of the indicators to evaluate the performance of adsorption materials [28-30].

In this study, using gasification fine slag foam flotation obtained carbon residue (GFSF) as raw material, the coal gasification fine slag residual carbon porous materials (GFSA) were prepared by alkali fusion-hydrothermal reaction, and the influence of some parameters (GFSF/KOH ratio, activation temperature and activation time) of the alkali fusion process was investigated. SEM and BET characterized the porosity of the material. The optimal product was used to remove $\mathrm{MB}$ from simulated wastewater. The effects of $\mathrm{pH}$, adsorption time, amount of adsorbent, and initial MB concentration on adsorption efficiency were studied and the adsorption behavior is discussed.

\section{Experiment}

\subsection{Raw Material}

The GFS sample was obtained from an entrained flow bed gasifier in Shenhua Ningxia Coal Industry Group Co., Ltd., Yinchuan, China. The raw material was dried at $105^{\circ} \mathrm{C}$ for $6 \mathrm{~h}$ to remove moisture and stored in a sealed bag at room temperature.

The foam flotation test was used to pretreat GFS. The froth floatation test was carried out by an XFD-type floatation machine (Ganzhou, China) having a capacity of $1 \mathrm{~L}$ and the slurry concentration was maintained at $100 \mathrm{~g} / \mathrm{L}$. The dried GFS was mixed with distilled water and poured into the flotation tank. The grout was first stirred at a speed of $1800 \mathrm{r} / \mathrm{min}$ for $2 \mathrm{~min}$, and then a certain amount of collector $(7 \mathrm{~kg} / \mathrm{t})$ and frother $(14 \mathrm{~kg} / \mathrm{t})$ were added 
successively. After stirring evenly, the air valve was opened to keep the gas flow rate at $0.2 \mathrm{~m}^{3} / \mathrm{h}$, and the bubbles were scraped. After repeating three times, the residual carbon and tail ash were obtained [31]. The loss on ignition of the residual carbon was $69.54 \%$. The gasification fine slag foam flotation obtained carbon residue (GFSF) was used in subsequent experiments. The separated tail ash had a higher ash purity and could be used to prepare zeolite, as detailed in our previous study [30]. The loss on ignition of GFS and GFSF was $26.12 \%$ and $69.54 \%$.

Potassium hydroxide $(\mathrm{KOH})$, sodium hydroxide $(\mathrm{NaOH})$, and hydrochloric acid $(\mathrm{HCl})$ were AR-grade, purchased from Aladdin Co., Ltd. (Shanghai, China). Methylene blue trihydrate (MB) was AR-grade from Tianjin Kemiou Chemical Reagent Co., Ltd. (Tianjin, China). Collector (W501) and frother (W502) was purchased from Hunan Xinghui Washing Chemical Technology Development Co., Ltd. (Zhuzhou, China).

\subsection{Preparation of Coal Gasification Fine Slag Residual Carbon Porous Material (GFSA)}

$\mathrm{KOH}$ and GFSF samples were ground and mixed in a mortar at a predetermined ratio, which varied from 1 to $4 \mathrm{~g} / \mathrm{g}$, put into a porcelain boat, and heated in a tubular furnace for the activation test. The test was carried out under a continuous nitrogen flow of $200 \mathrm{~mL} / \mathrm{min}$ and the heating rate was $10{ }^{\circ} \mathrm{C} / \mathrm{min}$. We heated the mixture to $750-900{ }^{\circ} \mathrm{C}$ and kept it at the final temperature for 30-120 min. After the activated sample was cooled to room temperature, it was rinsed to neutrality with distilled water, dried at $105^{\circ} \mathrm{C}$ for $6 \mathrm{~h}$, and sealed for storage.

\subsection{Characterization Methods}

$\mathrm{N}_{2}$ adsorption-desorption isotherms were obtained at $-196{ }^{\circ} \mathrm{C}$ after degassing at $150{ }^{\circ} \mathrm{C}$ for $6 \mathrm{~h}$ using a volumetric sorption analyzer (IQ2MP-XR (Florida, USA)). The Brunauer-Emmett-Teller (BET) model was adopted for specific surface area analysis. The pore volume, pore size distribution, and average pore diameter were measured using the Barrett-Joyner-Halenda (BJH) and Horvath-Kawazoe (HK) models [31-33]. The morphologies of the samples were characterized using a field-emission scanning electron microscope (SEM, ZEISS Gemini 500 (Heidenheim, Germany)) with LnLen mode.

The cation exchange capacity (CEC) of the samples was determined according to a modified ammonium acetate method used in the literature [34]. The tests for each sample were implemented 3 times. The errors were less than $\pm 5 \mathrm{mmol} / 100 \mathrm{~g}$.

\subsection{Adsorption Experiments}

The adsorption experiment was conducted in a temperature-controlled water-bath shaker, with the GFSA sample obtained under the optimum condition. A stock MB solution $(100 \mathrm{mg} / \mathrm{L})$ was prepared by diluting MB with deionized water and experimental solutions were prepared from its dilution. The desired amount of the adsorbents was added to an MB solution $(50 \mathrm{~mL})$ with varying concentrations in a shake flask $(100 \mathrm{~mL})$. The $\mathrm{pH}$ of the solution was controlled by adding $\mathrm{HCl}(0.1 \mathrm{~mol} / \mathrm{L})$ and $\mathrm{NaOH}(0.1 \mathrm{~mol} / \mathrm{L})$. The shake flasks were shaken at $27 \pm 0.5^{\circ} \mathrm{C}$ with a stirring speed of $120 \mathrm{rpm}$ for a certain time to achieve adsorption equilibrium. Then, the suspensions were filtered using membrane filters of $0.45 \mu \mathrm{m}$ pore size. MB concentration in the solution was measured at $665 \mathrm{~nm}$ using a UV-2500 spectrophotometer (Shimadzu (Shanghai, China)). During this process, the effects of contact time, initial adsorbate concentration, adsorbent dosage, and $\mathrm{pH}$ on the adsorption process were investigated. The adsorption capacity was calculated by using Equation (1):

$$
q_{e}=q_{t}=\left(C_{0}-C_{e, t}\right) V / m,
$$

where $q_{e}$ is the adsorption capacity at equilibrium $(\mathrm{mg} / \mathrm{g}), q_{t}$ is the adsorption capacity at time $\mathrm{t}(\mathrm{mg} / \mathrm{g}), \mathrm{C}_{0}$ is the initial concentration of $\mathrm{MB}(\mathrm{mg} / \mathrm{L}), C_{t}$ is the $\mathrm{MB}$ concentration at time $\mathrm{t}(\mathrm{mg} / \mathrm{L}), C_{e}$ is the MB equilibrium concentration $(\mathrm{mg} / \mathrm{L}), m$ is the actual amount of GFAS (g), and $V$ is the solution volume (L). 
The removal efficiency $(\eta)$ of the dye was determined using Equation (2):

$$
\eta(\%)=100\left(C_{0}-C_{e}\right) / C_{0}
$$

\section{Results and Discussion}

\subsection{Effect of Activation Parameters on Preparation of GFSA}

Cation exchange capacity (CEC) is an important index for rating adsorption materials, which reflects the cation exchange capacity of porous materials. The higher CEC of the adsorbent material means that there are a large number of adsorption sites inside the material, and its saturated adsorption capacity is also larger. The CEC of GFSF was $27.17 \mathrm{mmol} / 100 \mathrm{~g}$. The influence of different operating conditions on the CEC value of GFSA is shown in Figure 2. In the experiment (Figure 2a), the activation temperature $\left(800{ }^{\circ} \mathrm{C}\right)$ and the activation time $(90 \mathrm{~min})$ remained unchanged, GFSF $/ \mathrm{KOH}$ mass ratios ranged from 1 to $4 \mathrm{~g} / \mathrm{g}$. The CEC of GFSA obtained by activation with different mass ratios firstly increased and then decreased. When the GFSF/KOH mass ratio was $2 \mathrm{~g} / \mathrm{g}$, the CEC of GFSA reached the maximum. The concise diagram of the reaction mechanism of $\mathrm{KOH}$ and $\mathrm{C}$ is shown in Figure 1. KOH reacted with C in GFSF (Equations (3)-(5)) to generate $\mathrm{K}_{2} \mathrm{CO}_{3}, \mathrm{~K}_{2} \mathrm{O}, \mathrm{H}_{2}$, and $\mathrm{CO}$ in the activation process [35].

$$
\begin{gathered}
4 \mathrm{KOH}+\mathrm{C}=\mathrm{K}_{2} \mathrm{CO}_{3}+\mathrm{K}_{2} \mathrm{O}+2 \mathrm{H}_{2} \uparrow \\
\mathrm{K}_{2} \mathrm{CO}_{3}+2 \mathrm{C}=2 \mathrm{~K}+3 \mathrm{CO} \uparrow \\
\mathrm{K}_{2} \mathrm{O}+\mathrm{C}=2 \mathrm{~K}+\mathrm{CO} \uparrow
\end{gathered}
$$

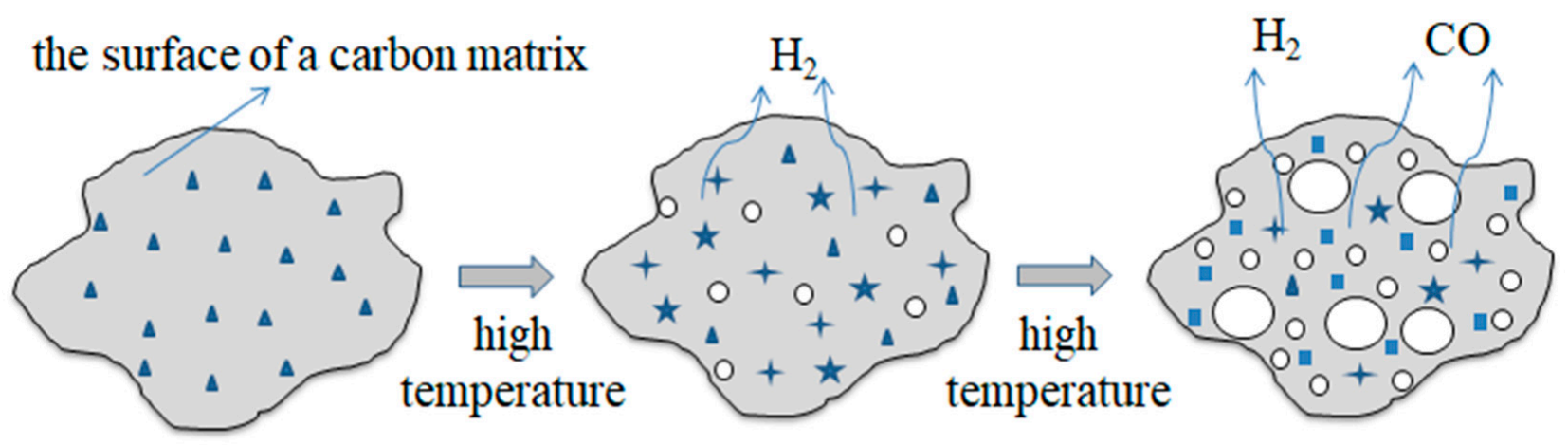

\section{$\Delta: \mathrm{KOH}, \quad+: \mathrm{K}_{2} \mathrm{O}, \star \mathrm{K}_{2} \mathrm{CO}_{3}, \quad \square: \mathrm{K}, 0:$ pore with different particle sizes.}

Figure 1. The concise diagram of the reaction mechanism of $\mathrm{KOH}$ and carbon in GFSF.

After the reaction rose to a certain temperature, the potassium ions (K) dispersed in GFSF reacted with carbon atoms (C) which led to the pores, wherein $\mathrm{K}_{2} \mathrm{CO}_{3}$ and $\mathrm{K}_{2} \mathrm{O}$ obtained by the reaction continued to react with $\mathrm{C}$ in GFSF to further form pores [16]. When the content of activator $\mathrm{KOH}$ was relatively low, $\mathrm{KOH}$ could only activate with a small amount of $\mathrm{C}$ in GFSF, and could not form enough pores. With the increase in $\mathrm{KOH}$, more $\mathrm{C}$ in GFSF participated in the activation reaction, which gradually increased the number of micropores and mesopores. Therefore, the CEC of GFSA was increased. The selective activation of $\mathrm{KOH}$ consumed mainly the carbon atoms located at the active site and left a large number of pores in the carbon matrix so that the specific surface area and pore volume of the activated carbon increased [35]. However, as the mass ratio of GFSF/KOH increased, after the $C$ in the active site of GFSF was completely reacted, the $C$ on the pore framework participated in the reaction leading to the collapse of micropores or mesopores to form macropores, so the CEC value of GFSA decreased. Activation temperature also influenced the CEC of the activated sample, due to various reactions that occurred in the activation 
process. The CEC of GFSA was enhanced by the increase in activation temperature up to $800{ }^{\circ} \mathrm{C}$, then decreased (Figure $2 \mathrm{~b}$ ) GFSF/ KOH mass ratio ( $2 \mathrm{~g} / \mathrm{g}$ ) and activation time (90 $\mathrm{min}$ ) remained unchanged). As the temperature of the reaction increased, the number of pores generated increased due to the acceleration of the activation reaction rate. Moreover, the boiling point of metallic potassium is $762{ }^{\circ} \mathrm{C}$. When the temperature exceeded its boiling point, potassium vapor flooded into the generated pores and the interlayer of graphite microcrystals, which promoted the activation reaction and generated more pores $[10,36]$. Therefore, when the activation temperature was $750{ }^{\circ} \mathrm{C}$ to $800{ }^{\circ} \mathrm{C}$, the adsorption sites increased because the material had more pores, and the CEC of GFSA increased significantly. At $850{ }^{\circ} \mathrm{C}$ and $900{ }^{\circ} \mathrm{C}$, the activation reaction further intensified, and the surface area and pore volume declined dramatically, due to the merging and collapse of pores caused by the overreaction of carbon and intense release of gas [37]. Hence, the activation temperature of $800{ }^{\circ} \mathrm{C}$ was the best choice for subsequent experiments. The effect of activation time on the CEC of GFSA was studied at an activation temperature of $800^{\circ} \mathrm{C}$ and $\mathrm{KOH} / \mathrm{CGS}$ mass ratio of $2.0 \mathrm{~g} / \mathrm{g}$ (Figure 2c). Activation times of $30 \mathrm{~min}$ and $60 \mathrm{~min}$ were not sufficient to generate a well-developed porosity, leading to a lower CEC of the activated samples. In the activation reaction process, there were a pore opening effect and a pore expanding effect [38]. In the early stage of the reaction process, a large number of micropores were generated, which was mainly the opening process of pores, so the CEC of activated samples in this process also increased. With the increase in reaction time, the effect of pore expansion was predominant, and the micropores and mesopores in the activated samples collapsed and merged to form macropores or the pores disappeared. Thus, when the activation time was extended by $120 \mathrm{~min}$, the CEC of the activated samples was reduced again. According to the above, the optimal activation conditions for GFSA were as follows: the mass ratio of GFSF/ $\mathrm{KOH}$ was $2 \mathrm{~g} / \mathrm{g}$, the activation temperature was $800{ }^{\circ} \mathrm{C}$, and the activation time was $90 \mathrm{~min}$. The CEC of GFSA was $110.68 \mathrm{mmol} / 100 \mathrm{~g}$ under the optimum conditions. Compared with the process conditions of biomass-based activated carbon studied by some researchers [39-41], the activation temperature of GFSF was higher and the time was longer. The reason may be that the production of GFS undergoes a high-temperature gasification and chilling process, in which the carbon that has not participated in the gasification reaction is carbonized at an excessively high temperature, so that the graphite crystallites in the carbonized product are changed in an orderly manner, and the gap between the crystallites is reduced. Therefore, the requirements for subsequent activation conditions are increased [42].
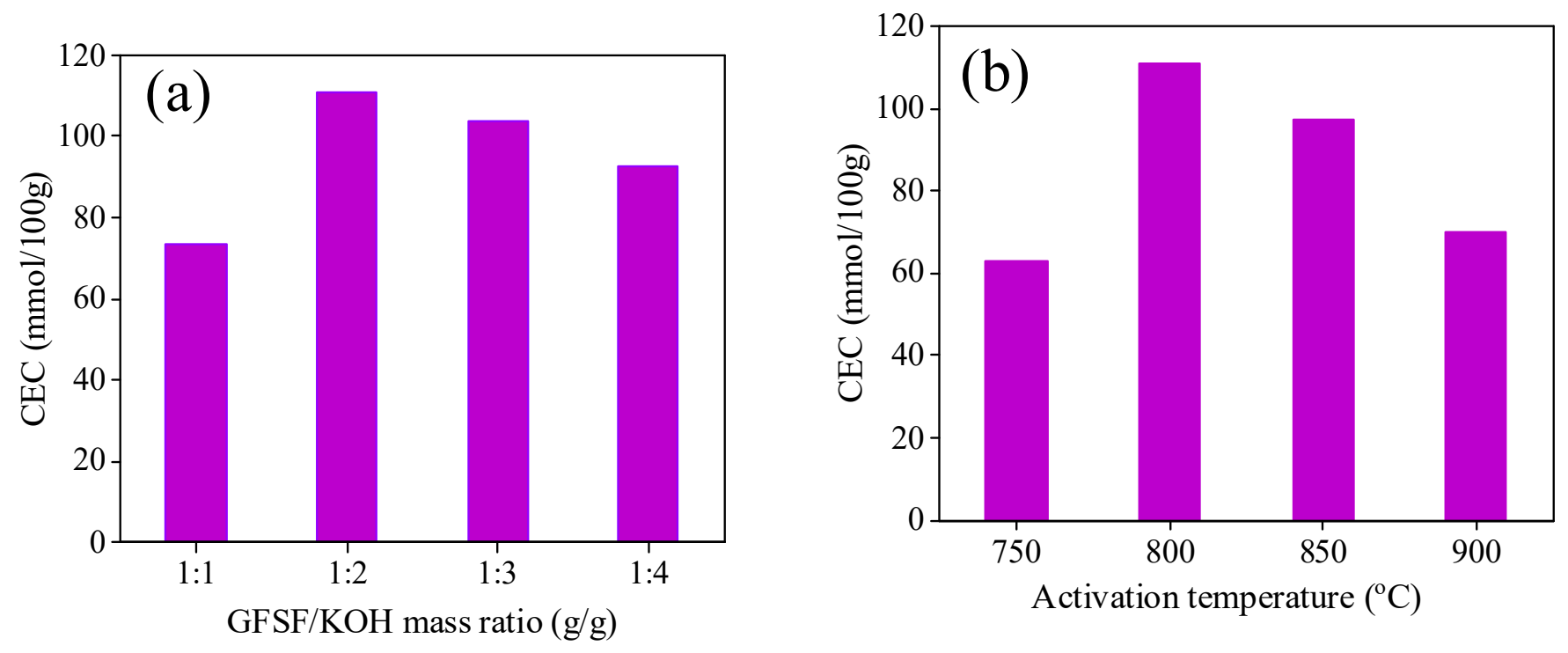

Figure 2. Cont. 


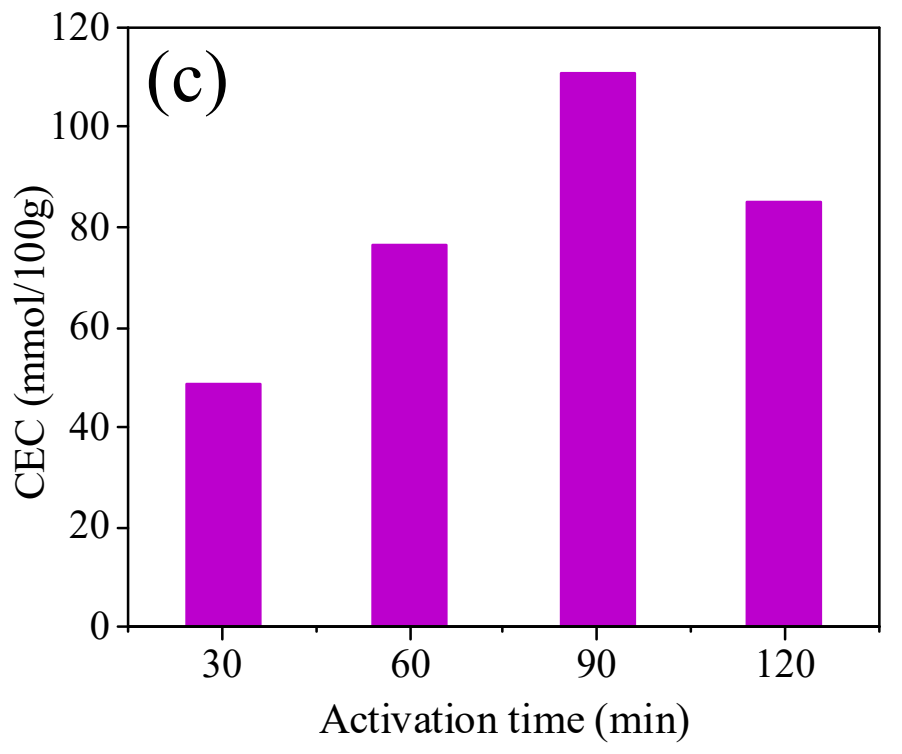

Figure 2. Effect of operation conditions on the cation exchange capacity (CEC) of GFSA: (a) gasification fine slag foam flotation obtained carbon residue (GFSF)/ $\mathrm{KOH}$ mass ratio, (b) activation temperature, and (c) activation time.

\subsection{Characterization of Materials}

The mineralogy and morphology of GFSA prepared under the optimal process conditions and GFSF were analyzed. Figure 3 shows the SEM images of samples with different CEC. GFSF is composed of irregular residual carbon particles and spherical mineral particles, and some spherical mineral particles have almost adhered to the surface of the residual carbon [31]. The sample with a CEC value of $27.17 \mathrm{mmol} / 100 \mathrm{~g}$ was GFSF, and its morphology is shown in Figure 3a. There were almost no pores on the surface of carbon particles and a small number of molten mineral particles on the surface. Due to the release of gases and volatile compounds, there were obvious pores on the external surface of the carbon matrix, as shown in Figure $3 \mathrm{~b}$ (GFSF/KOH mass ratio: 1:2, activation temperature: $800{ }^{\circ} \mathrm{C}$, activation time: $30 \mathrm{~min}$ ) and $3 \mathrm{c}(\mathrm{GFSF} / \mathrm{KOH}$ mass ratio: 1:2, activation temperature: $750{ }^{\circ} \mathrm{C}$, activation time: $90 \mathrm{~min}$ ). However, due to the shorter activation time and lower activation temperature, the sample had fewer pores and was microporous [43,44]. The pore of Figure $3 c$ was larger than that of Figure $3 b$, so the CEC of the sample in Figure $3 c$ is slightly higher. In Figure $3 \mathrm{~d}$ (GFSF/KOH mass ratio: 1:4, activation temperature: $800{ }^{\circ} \mathrm{C}$, activation time: $90 \mathrm{~min}$ ), more pore structures were observed, with slit pores appearing. Some block pores appeared on the surface of the carbon matrix shown in Figure $3 \mathrm{f}$ (GFSF/KOH mass ratio: 1:2, activation temperature: $800^{\circ} \mathrm{C}$, activation time: $120 \mathrm{~min}$ ). This may be because of excessive activation time and too high mass ratio of GFSF/KOH, which caused the activation strength to be too high, which caused the pore size to become larger or collapse and reduce the CEC $[35,37]$. The CEC of the sample in Figure 3e (GFSF/KOH mass ratio: 1:2, activation temperature: $800{ }^{\circ} \mathrm{C}$, activation time: $90 \mathrm{~min}$ ) was the largest, with abundant and relatively uniform circular pores distributed on its surface. 

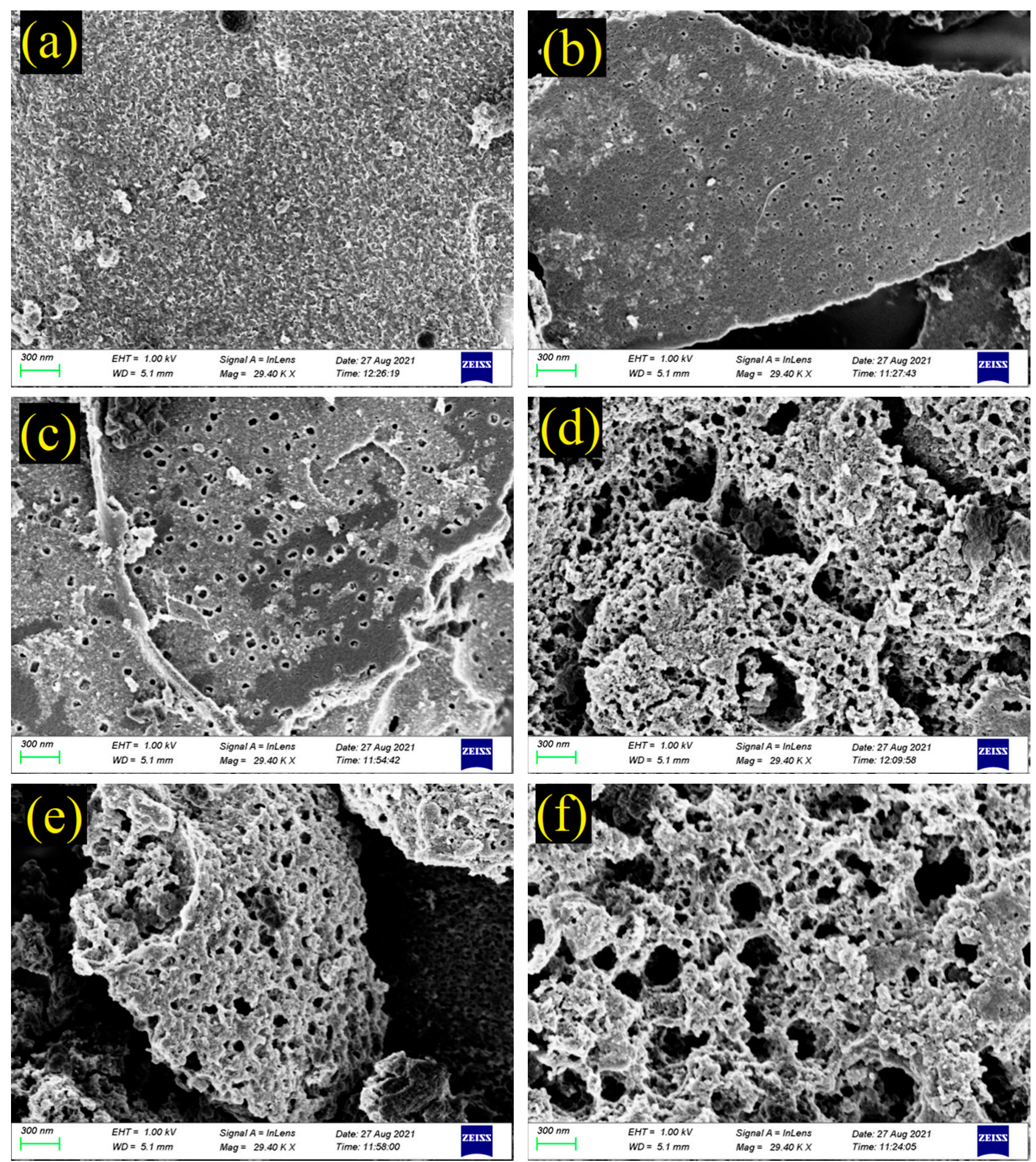

Figure 3. The SEM images of samples with different cation exchange capacity (CEC). (a) CEC = 27.17 $\mathrm{mmol} / 100 \mathrm{~g}$, (b) $\mathrm{CEC}=48.57 \mathrm{mmol} / 100 \mathrm{~g}$, (c) CEC $=62.85 \mathrm{mmol} / 100 \mathrm{~g}$, (d) CEC = 92.51 mmol $/ 100 \mathrm{~g}$, (e) CEC = $110.68 \mathrm{mmol} / 100 \mathrm{~g}$, and (f) $\mathrm{CEC}=85.03 \mathrm{mmol} / 100 \mathrm{~g}$.

$\mathrm{N}_{2}$ adsorption-desorption isotherms of GFSF and GFSA are shown in Figure 4, where GFSA was the sample prepared under the best process conditions. The GFSF and GFSA had a certain volume increment in all relative pressure ranges, which conformed to class IV adsorption isotherms and formed an obvious H4 hysteresis loop with the desorption curve (relative pressure range 0.4-0.99), indicating that they had a typical mesoporous structure [6,45]. As can be seen from Figure 4, the adsorption capacity of GFSA was 
significantly higher than that of GFSF. This is consistent with the SEM diagram in Figure 3. The GFSA shown in Figure 3e had complex pores, while the surface of the GFSF sample shown in Figure 3a had no obvious pores. The pore size distribution and pore properties of GFSF and GFSA are shown in Figure 5 and Table 1. The pores of GFSF mainly existed in the form of mesopores with fewer micropores, so its average pore size was larger than that of GFSA. The number of GFSA micropores obtained after GFSF activation was greatly increased (Figure 5), and the micropore volume $\left(\mathrm{V}_{\text {micro }}\right)$ and micropore rate $\left(\mathrm{V}_{\text {micro }} / \mathrm{V}_{\text {total }}\right)$ grew (Table 1), which was conducive to the application of adsorption. The total specific surface area $\left(\mathrm{S}_{\mathrm{BET}}\right)$ and total pore volume $\left(\mathrm{V}_{\text {total }}\right)$ of GFSA were greater than those of the raw material GFSF.

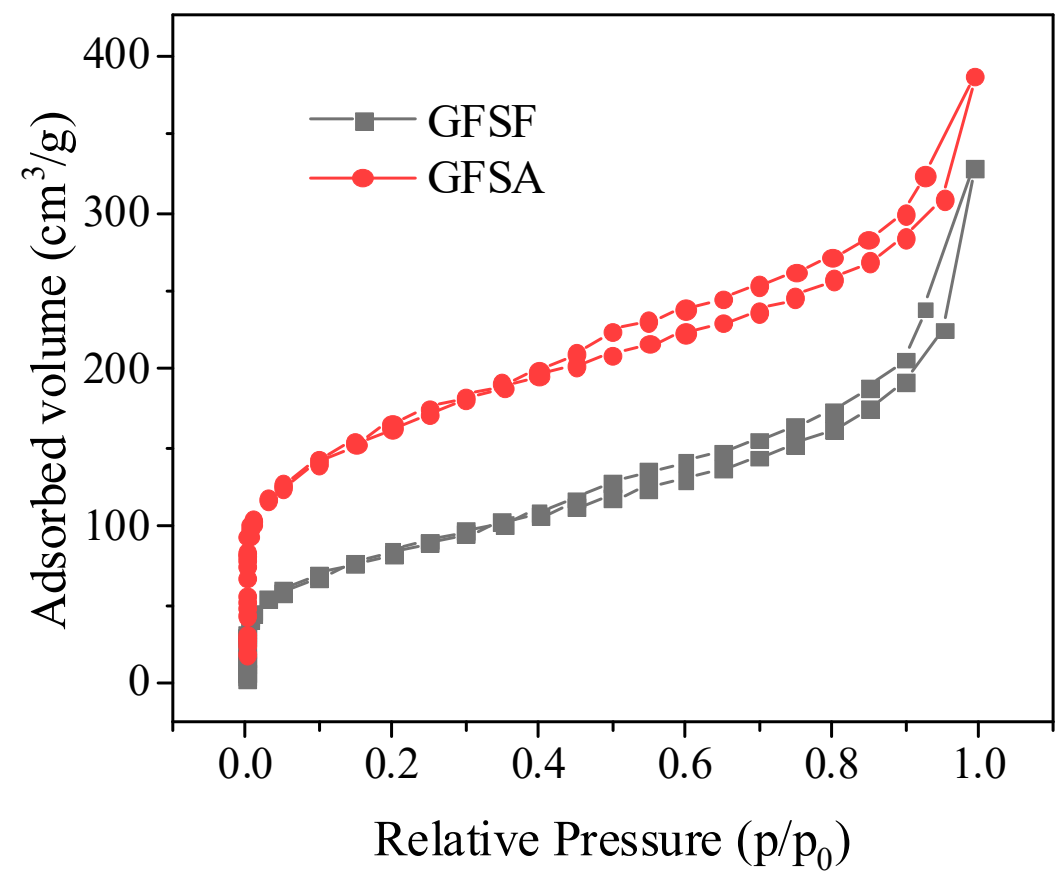

Figure 4. $\mathrm{N}_{2}$ adsorption-desorption isotherms of gasification fine slag foam flotation obtained carbon residue (GFSF) and coal gasification fine slag residual carbon porous material (GFSA).

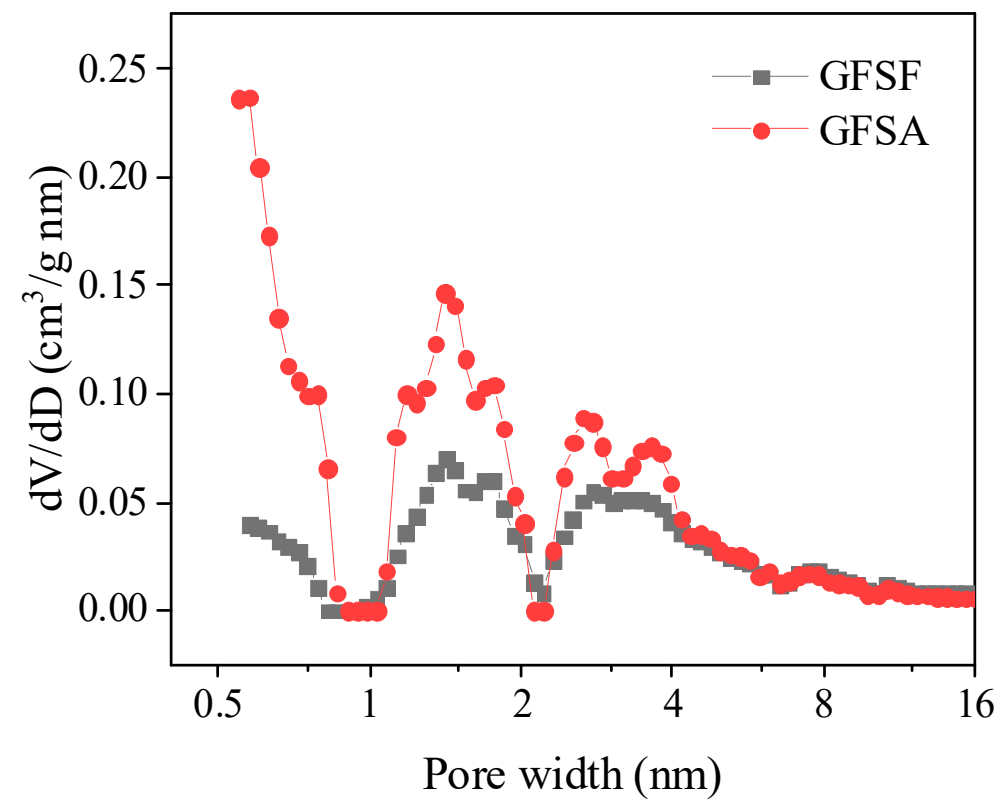

Figure 5. Pore size distribution of gasification fine slag foam flotation obtained carbon residue (GFSF) and coal gasification fine slag residual carbon porous material (GFSA). 
Table 1. Pore properties of gasification fine slag foam flotation obtained carbon residue (GFSF) and coal gasification fine slag residual carbon porous material (GFSA).

\begin{tabular}{|c|c|c|c|c|c|c|c|}
\hline Samples & $\mathrm{S}_{\mathrm{BET}}\left(\mathrm{m}^{2} / \mathrm{g}\right)$ & $\mathrm{V}_{\text {total }}\left(\mathrm{cm}^{3} / \mathrm{g}\right)$ & $\begin{array}{l}V_{\text {micro }} \\
\left(\mathrm{cm}^{3} / \mathrm{g}\right)\end{array}$ & $\begin{array}{l}V_{\text {meso }} \\
\left(\mathrm{cm}^{3} / \mathrm{g}\right)\end{array}$ & $\begin{array}{c}\mathrm{V}_{\text {micro }} / \mathrm{V}_{\text {total }} \\
(\%)\end{array}$ & $\begin{array}{c}\mathrm{V}_{\text {meso }} / \mathrm{V}_{\text {total }} \\
(\%)\end{array}$ & $\mathrm{D}_{\text {ave }}(\mathrm{nm})$ \\
\hline GFSF & 298.06 & 0.345 & 0.061 & 0.284 & 17.68 & 82.32 & 6.82 \\
\hline GFSA & 574.02 & 0.467 & 0.166 & 0301 & 35.55 & 64.45 & 4.17 \\
\hline
\end{tabular}

\subsection{Methylene Blue (MB) Adsorption Test}

3.3.1. Influence of Initial Solution $\mathrm{pH}$

The adsorption performance of adsorbents under different initial solution $\mathrm{pH}$ was investigated (Figure 6). As the $\mathrm{pH}$ changed from 2 to 10, the removal efficiency of $\mathrm{MB}$ by GFSA increased from $87 \%$ to $98 \%$. The main reason for this phenomenon is that MB is a cationic dye, most of which exists in the form of cations in aqueous solution, while a large number of $\mathrm{H}^{+}$ions in low $\mathrm{pH}$ solution compete and occupy the adsorption sites of $\mathrm{MB}^{+}$, so the removal efficiency is low. With the increase in solution $\mathrm{pH}$ value, the adsorption potential energy of functional groups on the surface of GFSA was dehydrogenated, and the negative charge increased, and the competition of $\mathrm{H}^{+}$ions in the solution was weakened, leading to the increase in adsorption capacity [46]. When the $\mathrm{pH}$ was greater than 8 , the removal efficiency of MB by the adsorbent GFSA was above $97 \%$, which achieved a good adsorption effect. Therefore, the $\mathrm{pH}$ of the initial solution in the following adsorption test is 8 .

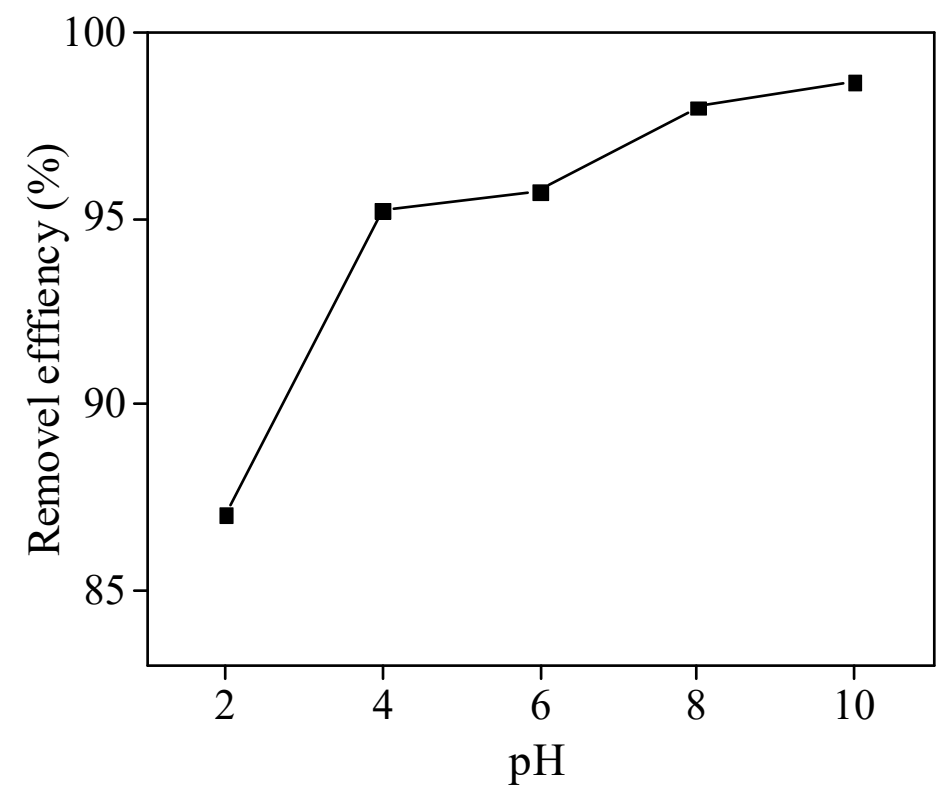

Figure 6. Influence of the solution $\mathrm{pH}$ on the removal efficiency of methylene blue (MB) by GFSA. (initial MB concentration: $50 \mathrm{mg} / \mathrm{L}$, adsorbent dosage: $3 \mathrm{~g} / \mathrm{L}$, contact time: $360 \mathrm{~min}$, and $\mathrm{T}=27 \pm 0.5^{\circ} \mathrm{C}$ ).

\subsubsection{Effect of Adsorbent Dosage}

The adsorption performance of adsorbents under different dosages was investigated, and the results are shown in Figure 7. The removal efficiency of MB increased gradually and then tended to be stable with the increase in GFSA dosage. When the dosage of GFSA exceeded $3 \mathrm{~g} / \mathrm{L}$, the removal efficiency increased slowly and remained unchanged with the increase in adsorbent, indicating that the adsorption basically reached equilibrium when the dosage was $3 \mathrm{~g} / \mathrm{L}$. In addition, the equilibrium adsorption capacity $\left(\mathrm{q}_{\mathrm{e}}\right)$ of the adsorbent decreased with the increase in adsorbent dosage. When the dosage was less than $3 \mathrm{~g} / \mathrm{L}$, the descending speed was relatively slow, and the descending rate was significantly enhanced when the dosage was greater than $3 \mathrm{~g} / \mathrm{L}$. This may be because increasing the 
amount of adsorbent can provide more adsorption sites when the concentration of $\mathrm{MB}$ solution is fixed. Although more MB was adsorbed on the adsorbent, the utilization rate of adsorbent per unit mass decreased. Therefore, $3 \mathrm{~g} / \mathrm{L}$ was chosen as the appropriate dosage.

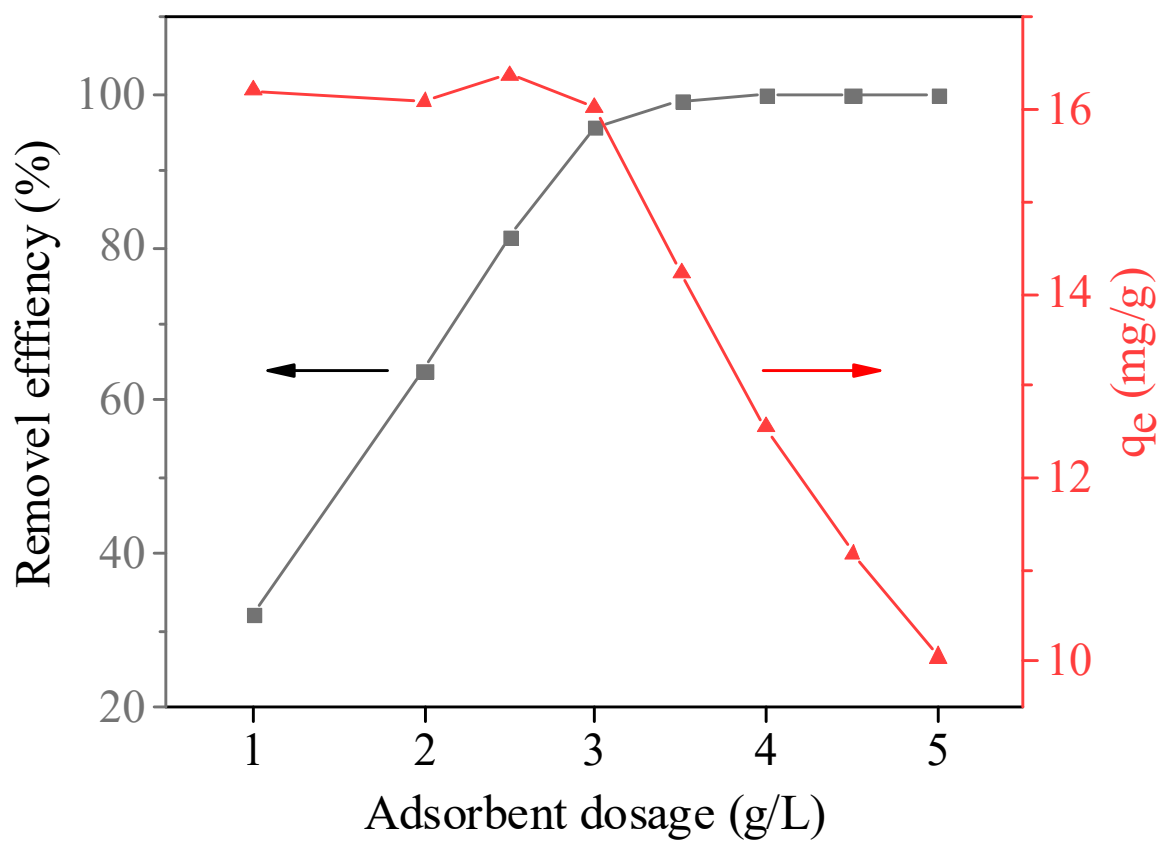

Figure 7. Influence of the adsorbent dosage on the removal efficiency of methylene blue (MB) and the MB adsorption capacity of the GFSA. (initial MB concentration: $50 \mathrm{mg} / \mathrm{L}$, initial solution $\mathrm{pH}: 8$, contact time: $360 \mathrm{~min}$, and $\mathrm{T}=27 \pm 0.5^{\circ} \mathrm{C}$ ).

\subsubsection{Adsorption Kinetics}

The adsorption behavior of the activated sample GFSA at different contact times was investigated (Figure 8a). In the range of 0-270 min, the adsorption capacity of MB on GFSA increased rapidly with time, while the adsorption capacity of GFSA changed slowly and gradually stabilized with time from 270 to $360 \mathrm{~min}$.

To better understand the adsorption kinetics of MB by GFSA, a pseudo-first-order kinetic model (PFO), pseudo-second-order kinetic model (PSO), and intraparticle diffusion model (IPD) were used to model the adsorption process [30,47], as shown in Figure 8b-d. The model parameters from the fitting calculation are shown in Tables 2 and 3 . The models are represented by

$$
\begin{aligned}
\frac{1}{q_{t}} & =\frac{1}{q_{e} k_{1} t}+\frac{1}{q_{e}}(\mathrm{PFO}) \\
\frac{t}{q_{t}} & =\frac{1}{k_{2} q_{e}^{2}}+\frac{t}{q_{e}}(\mathrm{PSO}) \\
q_{t} & =k_{d} \times t^{0.5}+\mathrm{C}(\mathrm{IPD})
\end{aligned}
$$

where $q_{t}(\mathrm{mg} / \mathrm{g})$ and $q_{e}(\mathrm{mg} / \mathrm{g})$ are the $\mathrm{MB}$ adsorption capacities at various and equilibrium times $t(\mathrm{~min})$, respectively; $k_{1}\left(\mathrm{~min}^{-1}\right), k_{2}\left(\mathrm{~g} \cdot \mathrm{mg}^{-1} \mathrm{~min}^{-1}\right)$, and $k_{d}\left(\mathrm{~g} \cdot \mathrm{mg}^{-1} \mathrm{~min}^{-0.5}\right)$ are the PFO, PSO, and IPD rate constants, respectively; and $C$ is a constant that involves the thickness and the boundary layer. 

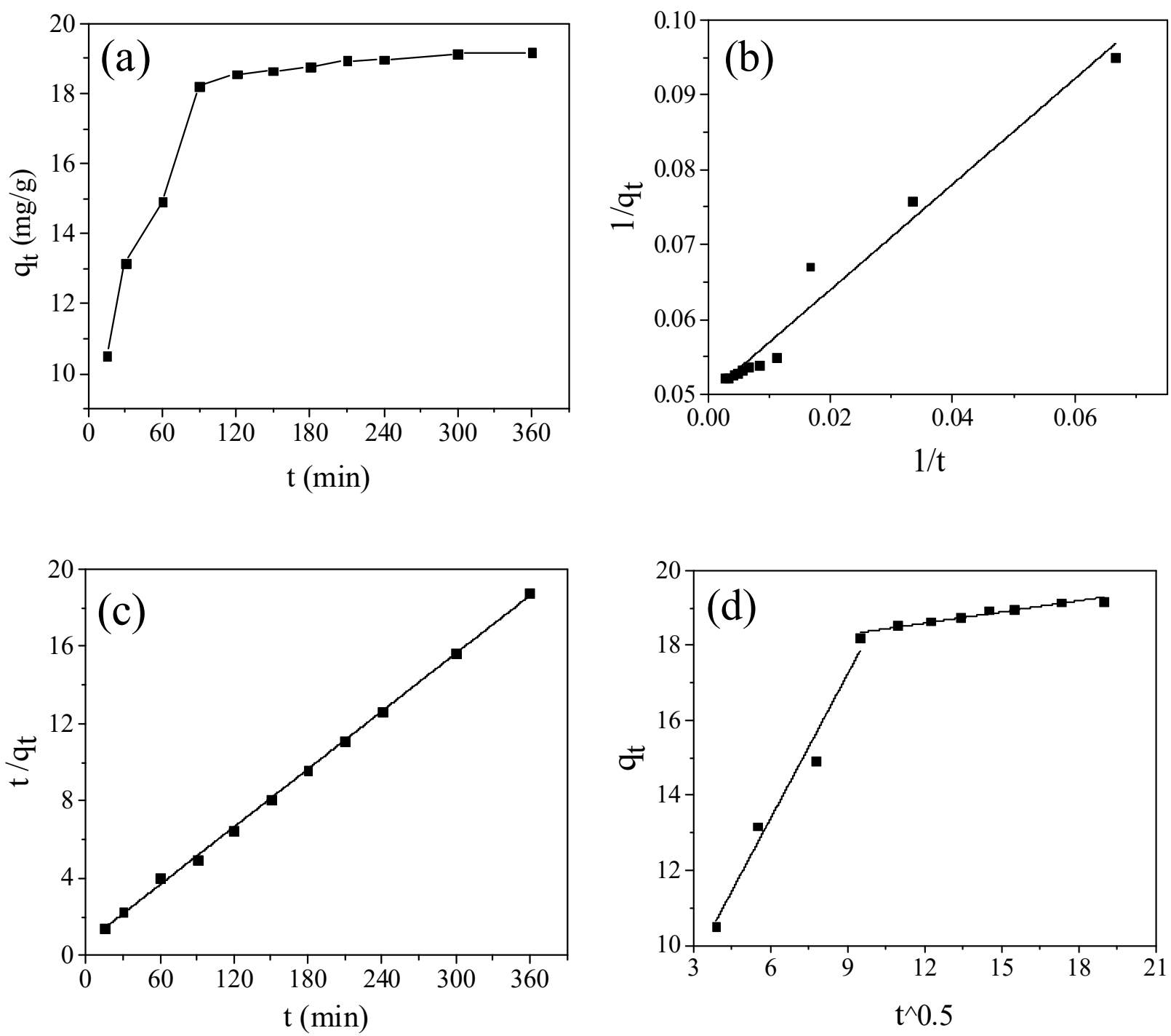

Figure 8. (a) Influence of time on the methylene blue (MB) adsorption capacity of the GFSA, (b) plots of $1 / \mathrm{q}_{\mathrm{t}}$ vs. $1 / \mathrm{t}$, (c) plots of $\mathrm{t} / \mathrm{q}_{\mathrm{t}} \mathrm{vs}$. $\mathrm{t}$, and (d) plots of $\mathrm{q}_{\mathrm{t}} \mathrm{vs}$. $\mathrm{t}^{0.5}$. (initial MB concentration:50 $\mathrm{mg} / \mathrm{L}$; adsorbent dosage: $3 \mathrm{~g} / \mathrm{L}$, initial solution $\mathrm{pH}: 8$, and $\left.\mathrm{T}=27 \pm 0.5^{\circ} \mathrm{C}\right)$.

Table 2. Parameters of the pseudo-first-order (PFO) and pseudo-second-order (PSO) kinetic models.

\begin{tabular}{cccccccc}
\hline \multirow{2}{*}{ Samples } & \multirow{2}{*}{$\mathbf{q}_{\mathbf{e}, \mathbf{e x p}}$} & \multicolumn{3}{c}{ PFO } & \multicolumn{3}{c}{ PSO } \\
\cline { 3 - 8 } & & $\mathbf{k}_{\mathbf{1}}$ & $\mathbf{q}$ e,cal & $\mathbf{R}^{\mathbf{2}}$ & $\mathbf{k}_{\mathbf{2}}$ & $\mathbf{q}_{\mathbf{e}, \mathrm{cal}}$ & $\mathbf{R}^{\mathbf{2}}$ \\
\hline GFSA & 19.1803 & 0.0707 & 20.0545 & 0.9728 & 0.0037 & 20.0438 & 0.9992 \\
\hline
\end{tabular}

Table 3. Parameters of the intraparticle diffusion (IPD) kinetic model.

\begin{tabular}{ccccccc}
\hline \multirow{2}{*}{ Samples } & \multicolumn{3}{c}{ Line 1: $\mathbf{t}=\mathbf{0 - 9 0}$ min } & \multicolumn{3}{c}{ Line 2: $\mathbf{t}>\mathbf{1 2 0} \mathbf{\text { min }}$} \\
\cline { 2 - 7 } & $\mathbf{k}_{\mathbf{1 d}}$ & $\mathbf{C}_{\mathbf{1}}$ & $\mathbf{R}_{\mathbf{1}}{ }^{2}$ & $\mathbf{k}_{\mathbf{2 d}}$ & $\mathbf{C}_{\mathbf{2}}$ & $\mathbf{R}_{\mathbf{2}}{ }^{\mathbf{2}}$ \\
\hline GFSA & 1.2848 & 5.6636 & 0.9724 & 0.1001 & 17.3940 & 0.9363 \\
\hline
\end{tabular}

As can be seen from the results in Table 2 , since the correlation coefficient $\mathrm{R}^{2}$ of the PSO kinetic model is higher, the PSO kinetic model can more accurately describe the adsorption data than the PFO kinetic model. It indicates that there is an electron exchange between the adsorbent surface and adsorbate molecules [19]. In order to further clarify the control steps 
of the adsorption process rate, the mechanism of the adsorption process was described by the IPD model. As shown in Figure $8 d$, the plots of $q_{t}$ against $t^{\wedge} 0.5$ for MB adsorption by GFSA consisted of two linear parts, but the two straight lines did not pass through the origin of the coordinate. Therefore, it is inferred that intraparticle diffusion is not the only step of rate control, and many other adsorption mechanisms affect the rate at the same time. The correlation coefficient of the IPD model parameters (Table 3) $\mathrm{R}_{1}{ }^{2}(0.9724)$ was larger than $\mathrm{R}_{2}{ }^{2}$ (0.9363), and the adsorption rate constant $\mathrm{K}_{1 \mathrm{~d}}$ (1.2848) was larger than $\mathrm{K}_{2 \mathrm{~d}}$ (0.1001). These results indicate that the adsorption was mainly divided into two stages, and the outer surface of the adsorbent plays a major role. The first stage was the membrane diffusion process, MB molecules diffused from the solution to the outer surface of GFSA, and the adsorption rate of GFSA to MB was faster in the initial stage. In the second stage, MB molecules continued to diffuse into the microporous channels inside the GFSA and were adsorbed on the microporous surface, but the adsorption rate slowed down due to adsorption saturation.

\subsubsection{Adsorption Isotherms}

Figure 9a shows the influence of different initial concentrations of $\mathrm{MB}$ on the adsorption process. The adsorption of MB onto the GFSA gradually increased as the MB concentration increased until a maximum value was achieved. Since the dosage and solution volume of GFSA was constant, the adsorption capacity increased with the increase in initial concentration, but the residual amount of adsorbate also increased, hence, the MB removal efficiency will decrease. When the initial concentration reached a certain value, the adsorption reached equilibrium, and the adsorption value did not continue to improve.
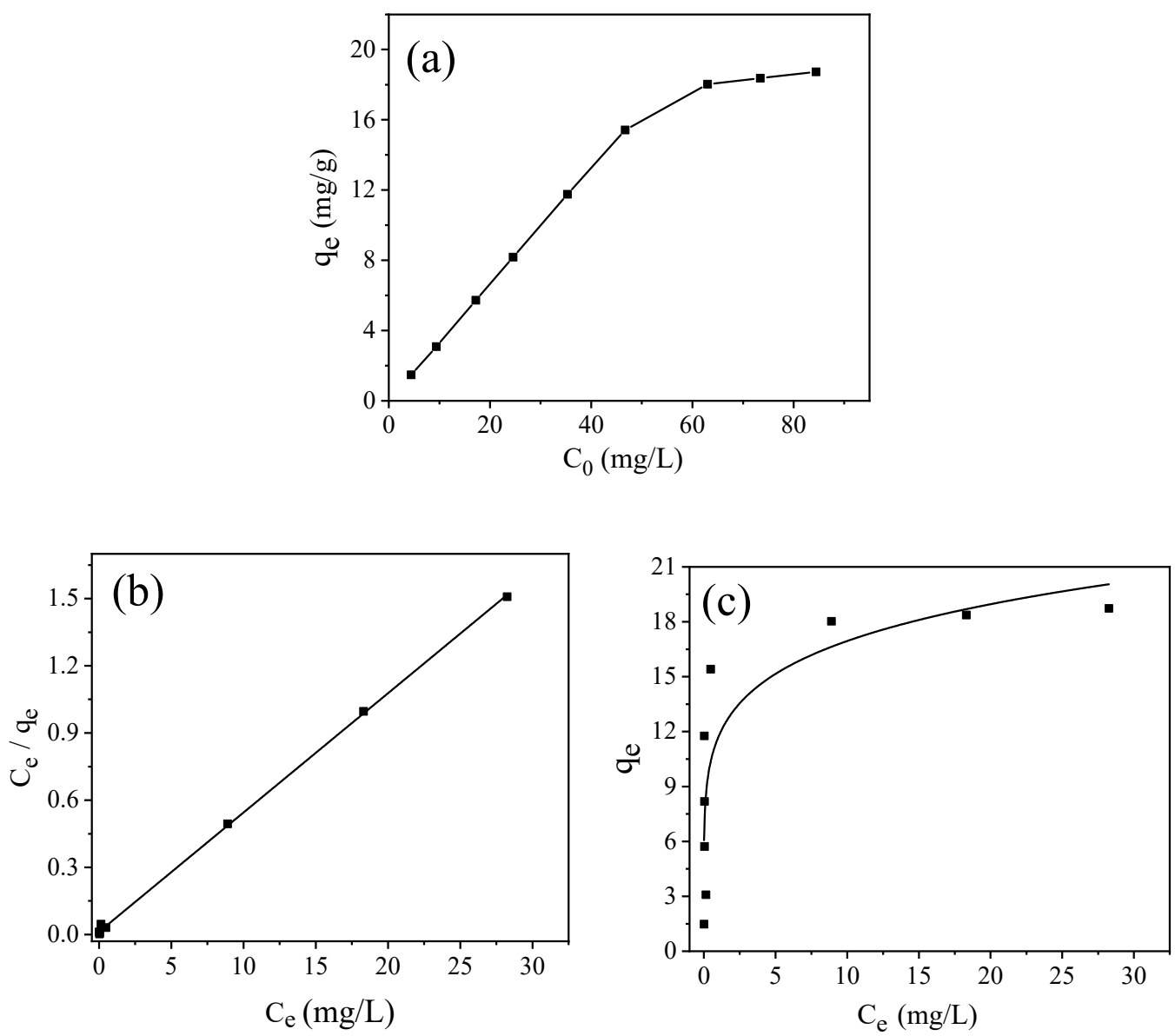

Figure 9. (a) Adsorption isotherm data for methylene blue (MB) adsorption onto the GFSA and (b) plots of $C_{e} / q_{e}$ vs. $C_{e}$, (c) plots of qe vs. $\mathrm{C}_{\mathrm{e}}$ (adsorbent dosage: $3 \mathrm{~g} / \mathrm{L}$, contact time: $360 \mathrm{~min}$, initial solution $\mathrm{pH}: 8$, and $\mathrm{T}=27 \pm 0.5^{\circ} \mathrm{C}$ ). 
In this section, two nonlinear isotherm models of Langmuir isotherm and Freundlich isotherm are used to explain the distribution of adsorbate molecules in equilibrium [48]. These isotherms are represented by

$$
\begin{gathered}
\frac{C_{e}}{q_{e}}=\frac{1}{K_{L} q_{m}}+\frac{C_{e}}{q_{m}} \\
q_{e}=K_{F} C_{e}^{1 / n}
\end{gathered}
$$

where $C_{e}(\mathrm{mg} / \mathrm{L})$ is the $\mathrm{MB}$ concentration at equilibrium, $q_{e}(\mathrm{mg} / \mathrm{g})$ is the equilibrium adsorption capacity of $\mathrm{MB}, q_{m}(\mathrm{mg} / \mathrm{g})$ is the maximum adsorption capacity of $\mathrm{MB}$, and $K_{L}(\mathrm{~L} / \mathrm{mg})$ and $K_{F}\left((\mathrm{mg} / \mathrm{g})(\mathrm{L} / \mathrm{mg})^{1 / \mathrm{n}}\right)$ are the constants of the Langmuir and Freundlich models, respectively.

The regression parameters of the Langmuir and Freundlich isotherms are shown in Table 4 . The fitting determination coefficient $\mathrm{R}^{2}$ of the Langmuir isotherm was 0.9995 , and the fitting determination coefficient $\mathrm{R}^{2}$ of the Freundlich isotherm was 0.7077 . Therefore, in this concentration range, the Langmuir adsorption isotherm model was more suitable for the MB adsorption test. According to the Langmuir isotherm calculation, the maximum adsorption capacity of GFSA to MB was $18.78 \mathrm{mg} / \mathrm{g}$, which was close to the experimental test value of $19.18 \mathrm{mg} / \mathrm{g}$. It showed that the adsorption sites on the surface of GFSA were evenly distributed, and MB formed monolayer adsorption on the surface of GFSA, and after reaching equilibrium, no migration of adsorbate molecules through the surface of the adsorbent was observed [49]. The value of $1 / n$ calculated by the Freundlich isotherm model was 0.16 in the range of $0-1$, indicating that the adsorption of MB on GFSA was feasible. Under this condition, the adsorption process can proceed [50]. Compared with the adsorption performance of adsorbents prepared with different wastes as raw materials studied by other researchers (Table 5), the adsorption capacity of porous materials prepared with gasification fine slag as raw materials in this paper can also be accepted. The preparation of adsorption materials from gasification fine slag can be further studied.

Table 4. Parameters of the Langmuir and Freundlich adsorption isotherms.

\begin{tabular}{ccccccc}
\hline \multirow{2}{*}{ Samples } & \multicolumn{3}{c}{ Langmuir Model } & \multicolumn{3}{c}{ Freundlich Model } \\
\cline { 2 - 7 } & $\mathbf{K}_{\mathbf{L}}$ & $\mathbf{q}_{\mathbf{m}}$ & $\mathbf{R}^{\mathbf{2}}$ & $\mathbf{K}_{\mathbf{F}}$ & $\boldsymbol{n}$ & $\mathbf{R}^{\mathbf{2}}$ \\
\hline GFSA & 4.3449 & 18.7759 & 0.9995 & 11.6796 & 6.1828 & 0.7077 \\
\hline
\end{tabular}

Table 5. Adsorption capacity of MB by adsorbents prepared from different waste materials.

\begin{tabular}{ccc}
\hline The Raw Material of Adsorbent & Adsorption Capacity $(\mathbf{m g} / \mathbf{g})$ & Ref. \\
\hline Date pits & 17.3 & {$[51]$} \\
Hazelnut shell & 8.82 & {$[52]$} \\
Kaolin & 16.34 & {$[53]$} \\
Coal fly ash & 16.6 & {$[54]$} \\
$\mathrm{Cu}_{2}$ O-geopolymer & 14.8 & {$[55]$} \\
Wheat shells & 16.56 & {$[56]$} \\
GFSF & 19.18 & This research \\
\hline
\end{tabular}

\section{Conclusions}

In the present study, coal gasification fine slag residual carbon porous materials (GSFA) were synthesized by chemical activation with KOH from GFSF. The porous composite had the highest CEC (110.68 mmol/100 g) under the optimal operation condition of a $\mathrm{GFSF} / \mathrm{KOH}$ mass ratio of $2 \mathrm{~g} / \mathrm{g}$, an activation temperature of $800{ }^{\circ} \mathrm{C}$, and activation treatment time of $90 \mathrm{~min}$. The GFSA with a total surface area of $574.02 \mathrm{~m}^{2} / \mathrm{g}$ was synthesized using GFSF. After activation, abundant pore structures were observed on the exterior surface of GFSA. The porosity of the porous material was the most important factor affecting 
its CEC. Furthermore, MB was selected as the target pollutant to evaluate the adsorption properties of the porous composite. The results show that the adsorption effect of GFSA on MB increased with the increase in the initial solution $\mathrm{pH}$. The pseudo-second-order kinetic model was more suitable for the fitting of equilibrium data, indicating that chemical adsorption mainly controls adsorption. Using the intraparticle diffusion model to fit the adsorption process was mainly in the stages of fast membrane diffusion and slow pore diffusion. The adsorption isotherm used the Langmuir isotherm model, which showed that the maximum single-layer adsorption capacity was $18.78 \mathrm{mg} / \mathrm{g}$. The results of this study demonstrated that solid waste GFS could be a reasonable raw material to produce low-cost porous adsorbent materials for the removal of MB.

Author Contributions: Conceptualization, Y.Z. and J.W.; methodology, F.G.; software, W.J.; figures, R.W.; investigation, Y.Z. and R.W.; literature search, G.Q.; data curation, R.W. and G.Q.; writingoriginal draft preparation, Y.Z.; writing-review and editing, F.G.; visualization, W.J.; investigation, Y.G.; project administration, J.W.; funding acquisition, J.W. All authors have read and agreed to the published version of the manuscript.

Funding: This work was supported by the Fundamental Research Funds for the Central Universities (No. 2017QNA25).

Institutional Review Board Statement: Not applicable.

Informed Consent Statement: Not applicable.

Data Availability Statement: Not applicable.

Conflicts of Interest: The authors declare no conflict of interest.

Sample Availability: Samples of the compounds are available from the authors.

\section{References}

1. Jie, D.; Xu, X.; Guo, F. The future of coal supply in China based on non-fossil energy development and carbon price strategies. Energy 2021, 220, 119644. [CrossRef]

2. Wang, X.; Tang, Y.; Wang, S.; Schobert, H.H. Clean coal geology in China: Research advance and its future. Int. J. Coal Sci. Technol. 2020, 7, 299-310. [CrossRef]

3. Filippov, S.P.; Keiko, A.V. Coal Gasification: At the Crossroad. Technological Factors. Therm. Eng. 2021, 68, 209-220. [CrossRef]

4. Zhao, X.; Zeng, C.; Mao, Y.; Li, W.; Peng, Y.; Wang, T.; Eiteneer, B.; Zamansky, V.; Fletcher, T. The Surface Characteristics and Reactivity of Residual Carbon in Coal Gasification Slag. Energy Fuels 2010, 24, 91-94. [CrossRef]

5. Pan, C.; Liang, Q.; Guo, X.; Dai, Z.; Liu, H.; Gong, X. Characteristics of Different Sized Slag Particles from Entrained-Flow Coal Gasification. Energy Fuels 2016, 30, 1487-1495. [CrossRef]

6. Tang, Y.; Guo, X.; Xie, Q.; Finkelman, R.B.; Han, S.; Huan, B.; Pan, X. Petrological Characteristics and Trace Element Partitioning of Gasification Residues from Slagging Entrained-Flow Gasifiers in Ningdong, China. Energy Fuels 2018, 32, 3052-3067. [CrossRef]

7. Huo, W.; Zhou, Z.; Guo, Q.; Yu, G. Gasification Reactivities and Pore Structure Characteristics of Feed Coal and Residues in an Industrial Gasification Plant. Energy Fuels 2015, 29, 3525-3531. [CrossRef]

8. Wang, Y.; Tang, Y.; Li, R.; Guo, X.; Hurley, J.P.; Finkelman, R.B. Measurements of the leachability of potentially hazardous trace elements from solid coal gasification wastes in China. Sci. Total Environ. 2021, 759, 143463. [CrossRef] [PubMed]

9. Wu, S.; Huang, S.; Wu, Y.; Gao, J. Characteristics and catalytic actions of inorganic constituents from entrained-flow coal gasification slag. J. Energy Inst. 2015, 88, 93-103. [CrossRef]

10. Zhang, Y.; Li, H.; Gao, S.; Geng, Y.; Wu, C. A study on the chemical state of carbon present in fine ash from gasification. Asia-Pac. J. Chem. Eng. 2019, 14, 14. [CrossRef]

11. Zhang, Y.; Li, H.; Wu, C. Study on distribution, chemical states and binding energy shifts of elements on the surface of gasification fine ash. Res. Chem. Intermed. 2019, 45, 3855-3864. [CrossRef]

12. Hu, D.; Hong, F.; Yun, T.; Hang, S. The Basic Characteristics of Gasification Slag from Texaco Gasifier and Shell Gasifier. Appl. Mech. Mater. 2014, 675-677, 728-732.

13. Miao, Z.; Wu, J.; Zhang, Y.; Zhao, X.; Guo, F.; Guo, Z.; Guo, Y. Chemical characterizations of different sized mineral-rich particles in fine slag from Entrained-flow gasification. Adv. Powder Technol. 2020, 31, 3715-3723. [CrossRef]

14. Liu, X.; Jin, Z.; Jing, Y.; Fan, P.; Qi, Z.; Bao, W.; Wang, J.; Yan, X.; Lv, P.; Dong, L. Review of the characteristics and graded utilisation of coal gasification slag. Chin. J. Chem. Eng. 2021, 35, 92-106. [CrossRef]

15. Wagner, N.J.; Matjie, R.H.; Slaghuis, J.H.; van Heerden, J.H.P. Characterization of unburned carbon present in coarse gasification ash. Fuel 2008, 87, 683-691. [CrossRef] 
16. Gu, Y.; Qiao, X. A carbon silica composite prepared from water slurry coal gasification slag. Microporous Mesoporous Mater. 2019, 276, 303-307. [CrossRef]

17. Miao, Z.; Guo, Z.; Qiu, G.; Zhang, Y.; Wu, J. Synthesis of activated carbon from high-ash coal gasification fine slag and their application to $\mathrm{CO}_{2}$ capture. J. $\mathrm{CO}_{2}$ Util. 2021, 50, 101585. [CrossRef]

18. Xu, Y.; Chai, X. Kinetic Studies of Degradation of Methyl Orange Dye Wastewater by Heterogeneous Fenton-like Using Coal Gasification Slag-based Activated Carbon-Fe. ShanDong Chem. Indstry 2016, 45, 159-164. [CrossRef]

19. Xu, Y.; Chai, X. Characterization of coal gasification slag-based activated carbon and its potential application in lead removal. Environ. Technol. 2018, 39, 382-391. [CrossRef]

20. Hassan, A.A.; Al-Isawi, R.; Saleh, Z.A. The Use of Pre-Heated Black Cumin Seeds (Nigella sativa) for Sorption Basic Dyes from Aqueous Solutions. J. Ecol. Eng. 2021, 22, 149-158. [CrossRef]

21. Alver, E.; Metin, A.Ü.; Brouers, F. Methylene blue adsorption on magnetic alginate/rice husk bio-composite. Int. J. Biol. Macromol. 2020, 154, 104-113. [CrossRef]

22. Patawat, C.; Silakate, K.; Chuan-Udom, S.; Supanchaiyamat, N.; Hunt, A.J.; Ngernyen, Y. Preparation of activated carbon from Dipterocarpus alatus fruit and its application for methylene blue adsorption. RSC Adv. 2020, 10, 21082-21091. [CrossRef]

23. Tan, I.A.W.; Ahmad., A.L.; Hameed., B.H. Adsorption of basic dye on high-surface-area activated carbon prepared from coconut husk: Equilibrium, kinetic and thermodynamic studies. J. Hazard. Mater. 2008, 154, 337-346. [CrossRef]

24. Ghumra, D.P.; Agarkoti, C.; Gogate, P.R. Improvements in effluent treatment technologies in Common Effluent Treatment Plants (CETPs): Review and recent advances. Process Saf. Environ. Prot. 2021, 147, 1018-1051. [CrossRef]

25. Madhav, S.; Ahamad, A.; Singh, P.; Mishra, P.K. A review of textile industry: Wet processing, environmental impacts, and effluent treatment methods. Environ. Qual. Manag. 2018, 27, 31-41. [CrossRef]

26. Novais, R.M.; Ascensão, G.; Tobaldi, D.M.; Seabra, M.P.; Labrincha, J.A. Biomass fly ash geopolymer monoliths for effective methylene blue removal from wastewaters. J. Clean. Prod. 2018, 171, 783-794. [CrossRef]

27. Ji, W.; Feng, N.; Zhao, P.; Zhang, S.; Zhang, S.; Lan, L.; Huang, H.; Li, K.; Sun, Y.; Li, Y.; et al. Synthesis of Single-Phase Zeolite A by Coal Gasification Fine Slag from Ningdong and Its Application as a High-Efficiency Adsorbent for $\mathrm{Cu} 2+$ and $\mathrm{Pb} 2+$ in Simulated Waste Water. ChemEngineering 2020, 4, 65. [CrossRef]

28. Shahrokhi-Shahraki, R.; Benally, C.; El-Din, M.G.; Park, J. High efficiency removal of heavy metals using tire-derived activated carbon vs commercial activated carbon: Insights into the adsorption mechanisms. Chemosphere 2021, 264, 128455. [CrossRef] [PubMed]

29. Yuliani, G.; Garnier, G.; Chaffee, A.L. Utilization of raw and dried Victorian brown coal in the adsorption of model dyes from solution. J. Water Process Eng. 2017, 15, 43-48. [CrossRef]

30. Zhang, Y.; Zhou, L.; Chen, L.; Guo, Y.; Guo, F.; Wu, J.; Dai, B. Synthesis of zeolite Na-P1 from coal fly ash produced by gasification and its application as adsorbent for removal of $\mathrm{Cr}(\mathrm{VI})$ from water. Front. Chem. Sci. Eng. 2020, 15, 518-527. [CrossRef]

31. Guo, F.; Miao, Z.; Guo, Z.; Li, J.; Zhang, Y.; Wu, J. Properties of flotation residual carbon from gasification fine slag. Fuel 2020, 267, 117043. [CrossRef]

32. Guo, F.; Zhao, X.; Guo, Y.; Zhang, Y.; Wu, J. Fractal analysis and pore structure of gasification fine slag and its flotation residual carbon. Colloids Surf. A Physicochem. Eng. Asp. 2020, 585, 124148. [CrossRef]

33. Kowalczyk, P.; Terzyk, A.P.; Gauden, P.A.; Rychlicki, G. Numerical Analysis of the Horvath-Kawazoe Equation-The Adsorption of Nitrogen, Argon, Benzene, Carbon Tetrachloride and Sulphur Hexafluoride. Adsorpt. Sci. Technol. 2016, 20, 295-305. [CrossRef]

34. Zhang, Y.; Dong, J.; Guo, F.; Shao, Z.; Wu, J. Zeolite Synthesized from Coal Fly Ash Produced by a Gasification Process for Ni ${ }^{2+}$ Removal from Water. Minerals 2018, 8, 116. [CrossRef]

35. Xing, B.; Zhang, C.; Pan, L.; Chen, M.; Liu, H. Study on the preparation of high specific surface are acoal-based activated carbon and its adsorption properties. Clean Carbon Technol. 2008, 14, 85-88. [CrossRef]

36. Romanos, J.; Beckner, M.; Rash, T.; Firlej, L.; Kuchta, B.; Yu, P.; Suppes, G.; Wexler, C.; Pfeifer, P. Nanospace engineering of KOH activated carbon. Nanotechnology 2012, 23, 015401. [CrossRef]

37. Wang, J.; Lei, S.; Liang, L. Preparation of porous activated carbon from semi-coke by high temperature activation with KOH for the high-efficiency adsorption of aqueous tetracycline. Appl. Surf. Sci. 2020, 530, 147187. [CrossRef]

38. Demiral, H.; Demiral, İ.; Karabacakoğlu, B.; Tümsek, F. Production of activated carbon from olive bagasse by physical activation. Chem. Eng. Res. Des. 2011, 89, 206-213. [CrossRef]

39. Van Thuan, T.; Quynh, B.T.P.; Nguyen, T.D.; Ho, V.T.T.; Bach, L.G. Response surface methodology approach for optimization of $\mathrm{Cu}^{2+}, \mathrm{Ni}^{2+}$ and $\mathrm{Pb}^{2+}$ adsorption using $\mathrm{KOH}$-activated carbon from banana peel. Surf. Interfaces 2017, 6, 209-217. [CrossRef]

40. Zhao, J.; Yu, L.; Ma, H.; Zhou, F.; Yang, K.; Wu, G. Corn stalk-based activated carbon synthesized by a novel activation method for high-performance adsorption of hexavalent chromium in aqueous solutions. J. Colloid Interface Sci. 2020, 578, 650-659. [CrossRef]

41. Jawad, A.H.; Saud Abdulhameed, A.; Wilson, L.D.; Syed-Hassan, S.S.A.; Alothman, Z.A.; Rizwan Khan, M. High surface area and mesoporous activated carbon from $\mathrm{KOH}$-activated dragon fruit peels for methylene blue dye adsorption: Optimization and mechanism study. Chin. J. Chem. Eng. 2021, 32, 281-290. [CrossRef]

42. Li, J.; Lu, X.; Zhang, H. Affecting factors of the coal based activated carbon quality. Clean Coal Technol. 2018, 24, 84-87. [CrossRef]

43. Sriramoju, S.K.; Dash, P.S.; Majumdar, S. Meso-porous activated carbon from lignite waste and its application in methylene Blue adsorption and coke plant effluent treatment. J. Environ. Chem. Eng. 2021, 9, 104784. [CrossRef] 
44. Song, G.; Deng, R.; Yao, Z.; Chen, H.; Romero, C.; Lowe, T.; Driscoll, G.; Kreglow, B.; Schobert, H.; Baltrusaitis, J. Anthracite coal-based activated carbon for elemental $\mathrm{Hg}$ adsorption in simulated flue gas: Preparation and evaluation. Fuel 2020, $275,117921$. [CrossRef]

45. Bandura, L.; Franus, M.; Józefaciuk, G.; Franus, W. Synthetic zeolites from fly ash as effective mineral sorbents for land-based petroleum spills cleanup. Fuel 2015, 147, 100-107. [CrossRef]

46. Chen, W.; Chen, F.; Ji, B.; Zhu, L.; Song, H. Insights into the mechanism of methylene blue removed by novel and classic biochars. Water Sci. Technol. 2019, 79, 1561-1570. [CrossRef] [PubMed]

47. Wang, K.; Peng, N.; Sun, J.; Lu, G.; Chen, M.; Deng, F.; Dou, R.; Nie, L.; Zhong, Y. Synthesis of silica-composited biochars from alkali-fused fly ash and agricultural wastes for enhanced adsorption of methylene blue. Sci. Total Environ. 2020, $729,139055$. [CrossRef]

48. Dinh, N.T.; Vo, L.N.H.; Tran, N.T.T.; Phan, T.D.; Nguyen, D.B. Enhancing the removal efficiency of methylene blue in water by fly ash via a modified adsorbent with alkaline thermal hydrolysis treatment. RSC Adv. 2021, 11, 20292-20302. [CrossRef]

49. Pathak, P.D.; Mandavgane, S.A. Preparation and characterization of raw and carbon from banana peel by microwave activation: Application in citric acid adsorption. J. Environ. Chem. Eng. 2015, 3, 2435-2447. [CrossRef]

50. Yağmur, H.K.; Kaya, I. Synthesis and characterization of magnetic $\mathrm{ZnCl}_{2}$-activated carbon produced from coconut shell for the adsorption of methylene blue. J. Mol. Struct. 2021, 1232, 130071. [CrossRef]

51. Banat, F.; Al-Asheh, S.; Al-Makhadmeh, L. Evaluation of the use of raw and activated date pits as potential adsorbents for dye containing waters. Process Biochem. 2003, 39, 193-202. [CrossRef]

52. Aygun, A.; Yenisoy-Karakas, S.; Duman, I. Production of granular activated carbon from fruit stones and nutshells and evaluation of their physical, chemical and adsorption properties. Microporous Mesoporous Mater. 2003, 66, 189-195. [CrossRef]

53. Ghosh, D.; Bhattacharyya, K.G. Adsorption of methylene blue on kaolinite. Appl. Clay Sci. 2002, 20, 295-300. [CrossRef]

54. Wang, S.; Ma, Q.; Zhu, Z. Characteristics of coal fly ash and adsorption application. Fuel 2008, 87, 3469-3473. [CrossRef]

55. Fallah, M.; MacKenzie, K.J.D.; Hanna, J.V.; Page, S.J. Novel photoactive inorganic polymer composites of inorganic polymers with copper(I) oxide nanoparticles. J. Mater. Sci. 2015, 50, 7374-7383. [CrossRef]

56. Bulut, Y.; Aydın, H. A kinetics and thermodynamics study of methylene blue adsorption on wheat shells. Desalination 2006, 194, 259-267. [CrossRef] 